\title{
Serum Magnesium and Copper Levels Amongst Pregnant Women in Mosul City
}

\author{
Luma M. Tohala \\ Department of Biochemistry \\ Nineveh College of Medicine \\ University of Mosul
}

(Received 4/ 4 / 2011 ; Accepted 20 / 6 / 2011 )

\begin{abstract}
The study was conducted in Mosul during the period from September 2010 to March 2011 including two groups: the first non-pregnant women and the second pregnant women composed of 40 and 120 apparently healthy women respectively. Pregnant group was subdivided equally according to their trimester into three subgroups, women in second and third trimester having ferrous sulphate supplement.

Serum magnesium and copper measurements were done for these groups of women. The results showed that serum magnesium concentration start to reduce significantly during first trimester continue to decline in second and third trimesters in comparison with nonpregnant group. Serum copper concentration start to increase significantly during first trimester continue to increase in second and third trimesters in comparison with nonpregnant group.
\end{abstract}

Keywords: Magnesium, Copper, Pregnancy, Trimester.

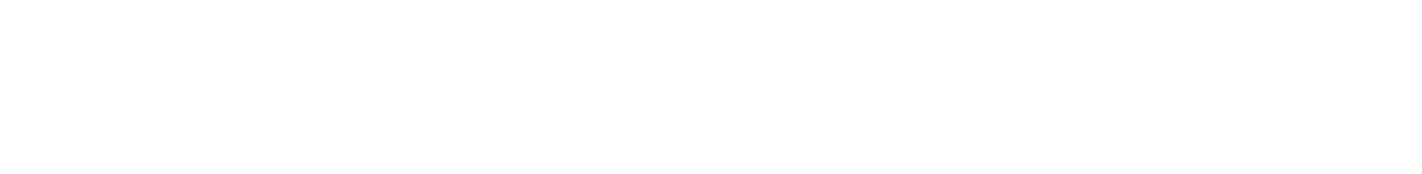

لجرريتْ الدرلسة في مدينِة الموصل خلال المدة مِّلْ أيلول 2010 إلى آذار 2011 متضمنة مجموعتين:

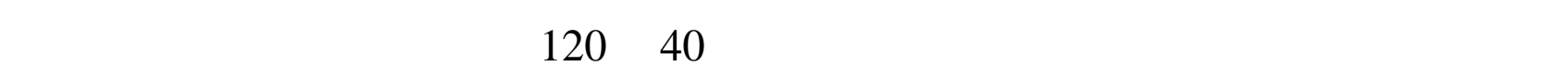

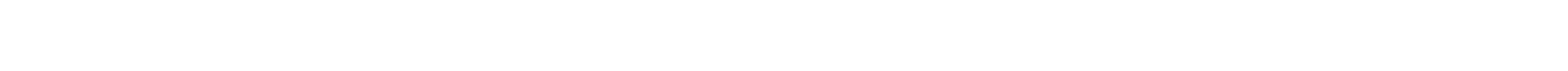

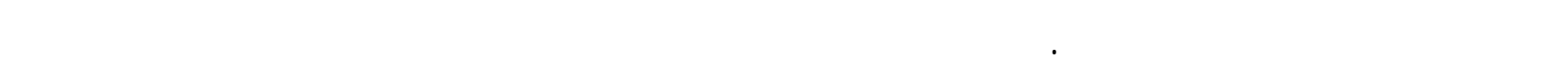
هذه المجلمبع.

دلت النتائج على أن تركيز المغنيسيوم بدأ بالانخفاض المعنوي أثناء الثُلث الأول من الحمل وواصل

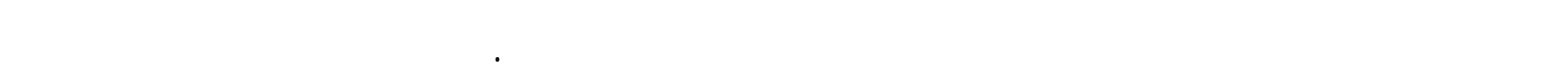
المعنوي أثناء الثلث الأول وواصل الارتفاع في الثلث الثاني والثالث. 


\section{INTRODUCTION}

The importance of mineral balance during pregnancy is still underestimated, though sedulous research demonstrates that trace elements and minerals are crucial for the development of fetus. Many minerals are transferred to the fetus for fetal stores in the latter part of the pregnancy, although they may play important developmental role during pregnancy (Burits et al., 2008). Certain essential macro- and micro-minerals are, for instance, constituents of, or interact with enzymes. Without proper enzyme functions, health and immunity suffers (Baig et al., 2003).

Nutritional deficiencies are common in pregnancy, but many pregnant women are taking unnecessary supplements of vitamins and minerals because they fail to understand the normal physiological and biochemical variations of pregnancy (Conradt et al., 1984; Sheldon et al., 1985).

Magnesium (Mg) is the fourth most abundant cation in the human body (Loyke, 2002). More than 300 enzymes that utiltze ATP require magnesium, [including enzymes involved in protein synthesis, glycolysis and the transmembrane transport of ions (Marshall and Bangert, 2008)]. Magnesium ions bind to Adenosin triphosphate (ATP) to form active ATP (Henry, 2001; Wardlaw and Hampl, 2007). A magnesium-ATP complex is the substrate for many ATP-requiring enzymes such as alkaline phosphatase, Hexokinase, fructokinase, phosphofructokinase, adenyl cyclase, cAMP dependent kinases, and others (Marshall and Bangert, 2008; Vasudevan and Sreekumari, 2005).

The normal serum magnesium level is $(0.66-1.07 \mathrm{mmol} / \mathrm{L})$. Out of this $60 \%$ is ionized, $10 \%$ is complexed with other ions and $30 \%$ is bound to proteins (Vasudevan and Sreekumari, 2005; Burits et al., 2008).

Magnesium has established its role in obstetrics with its relationship to both foetal and maternal wellbeing. The low concentration of magnesium in serum exposes the subject to a risk of pregnancy complications which includes pre-eclampsia. This is usually due to a defect in an enzymatic process which occurs as a result of low circulating magnesium to function as a co-factor (Akinloye et al., 2010). It has also been suggested that sudden infant death syndrome (SIDS) may be associated with magnesium deficiency found in the newborn (Durlach et al., 1991).

Copper $(\mathrm{Cu})$ is third most abundant trace element in the human body (Henry, 2001). It is an essential micronutrient and an important co-factor of several proteins and enzymes (Payne-James et al., 2001). These enzymes including (amine oxidase, copper - dependent superoxide dismutase, cytochrome oxidase and tyrosinase) (Murray et al., 2009; Etebary et al., 2010).

In iron metabolism, without copper, iron cannot be properly converted to its usable form and absorbed by the body. Copper also participates in melanine synthesis (Burits et al., 2008).

However, excess copper can cause problems because it can oxidize proteins and lipids, binds to nucleic acids and enhance the production of free radicals (Murray et al., 2009; Burits et al., 2008). It is thus important to have mechanisms that will maintain the amount of copper in the body within normal limits (Murray et al., 2009).

After Copper ingested in diet it carried to the liver bound to albumin, then is taken up by liver cells, and part of it is excreted in the bile. Copper ions also leave the liver attached to ceruloplasmin, which is synthesized in that organ (Murray et al., 2009). 
The present study aimed to find the levels of serum magnesium and copper in pregnant women, and follow the changes in $\mathrm{Mg}$ and $\mathrm{Cu}$ levels during the three trimesters of pregnancy in Mosul city. It was performed because of very few international and local studies provide information on elements levels in normal pregnancies. On the other hand, there is need for proper adequate and balanced micronutrient supplementation during pregnancy to affect a healthy outcome.

\section{PATIENTS AND METHODS}

This study was conducted during the period from September 2010 to March 2011, subjects enrolled in this study include 160 women, divided into two groups.

Group I considered as control composed of 40 apparently healthy non-pregnant women, with ages ranged from (18-38) years.

Group II composed of 120 apparently healthy pregnant women, with ages ranged from (18-38) years. According to pregnancy trimester this group was subdivided into three subgroups:

Subgroup A composed of 40 apparently healthy women in first trimester pregnancy, with ages ranged from (18-38) years.

Subgroup B composed of 40 apparently healthy women in second trimester pregnancy, with ages ranged from (18-37) years.

Subgroup C composed of 40 apparently healthy women in third trimester pregnancy, with ages ranged from (19-37) years.

A complete record of history was obtained, including name, age, duration of pregnancy, dietary habit, past-medical, past-surgical and drug history. All members included in the study had no significant past-medical and past-surgical history affecting $\mathrm{Mg}$ and $\mathrm{Cu}$ level or drug history of $\mathrm{Mg}$ and $\mathrm{Cu}$ administration. Group II members are on folate supplement while only the members of subgroup B and C are on ferrous sulphate supplement .

Venous blood samples for serum $\mathrm{Mg}$ and $\mathrm{Cu}$ concentration measurement were obtained from all subjects. The measurement was done by atomic absorption spectrophotometer (Pye Unicam P-CD9 instrument England).

The results were statistically evaluated by standard statistical methods using the mean $(\bar{X})$, standard deviation (SD), range (minimum-maximum), reference range, linear regression analysis (Pearson correlation coefficient r), student's t-test (Chap, 2003; Jones, 2002; Khachatryan and Nikos, 2000) and normal distribution curve with computer software programs including Microsoft excel 2003 and Statistical Package for the Social Sciences computer program (SPSS for windows, version 11.5). (Landau and Everitt, 2003) to evaluate the relation between the different parameters. Differences between the observations were considered significant at $p<0.05$. 
Table 1: Comparison between parameters of group I and II.

$\pm \mathrm{SD}, p$-value in comparison with group I $\overline{\mathrm{X}}$ values are presented as $p>0.05=$ non Significant

\begin{tabular}{|c|c|c|c|c|}
\hline Parameter & $\begin{array}{c}\text { Group I } \\
\text { Non-Pregnant } \\
n=40\end{array}$ & \multicolumn{3}{|c|}{$\begin{array}{l}\text { Group II Pregnant } \\
\qquad \mathbf{n}=120\end{array}$} \\
\hline \multirow{3}{*}{ Age (Years) } & \multirow{3}{*}{$24.8 \pm 4.6$} & \multicolumn{3}{|c|}{$\begin{array}{c}25.2 \pm 4.3 \\
p>0.05\end{array}$} \\
\hline & & Subgroup A & Subgroup B & Subgroup C \\
\hline & & $\begin{array}{c}24.3 \pm 4.2 \\
p>0.05\end{array}$ & $\begin{array}{c}25.8 \pm 4.3 \\
p>0.05\end{array}$ & $\begin{array}{c}25.6 \pm 4.2 \\
p>0.05\end{array}$ \\
\hline \multirow{3}{*}{$\begin{array}{l}\text { Serum Mg } \\
(\mathrm{mmol} / \mathrm{L})\end{array}$} & \multirow{3}{*}{$0.94 \pm 0.052$} & \multicolumn{3}{|c|}{$\begin{array}{c}0.75 \pm 0.105 \\
p<0.001\end{array}$} \\
\hline & & Subgroup A & Subgroup B & Subgroup C \\
\hline & & $\begin{array}{c}0.846 \pm 0.079 \\
p<0.001\end{array}$ & $\begin{array}{c}0.750 \pm 0.048 \\
p<0.001\end{array}$ & $\begin{array}{c}0.641 \pm 0.047 \\
p<0.001\end{array}$ \\
\hline \multirow{3}{*}{$\begin{array}{c}\text { Serum Cu } \\
(\mu \mathrm{mol} / \mathrm{L})\end{array}$} & \multirow{3}{*}{$19.78 \pm 2.08$} & \multicolumn{3}{|c|}{$\begin{array}{c}25.34 \pm 5.063 \\
p<0.001\end{array}$} \\
\hline & & Subgroup A & Subgroup B & Subgroup C \\
\hline & & $\begin{array}{c}21.45 \pm 2.64 \\
p<0.002\end{array}$ & $\begin{array}{c}25.58 \pm 2.56 \\
p<0.001\end{array}$ & $\begin{array}{c}31.84 \pm 3.06 \\
p<0.001\end{array}$ \\
\hline \multirow{3}{*}{ Parity number } & & \multicolumn{3}{|c|}{$2.15 \pm 1.71$} \\
\hline & & Subgroup A & Subgroup B & Subgroup C \\
\hline & & $2.31 \pm 1.70$ & $2.18 \pm 1.54$ & $2.13 \pm 2.17$ \\
\hline
\end{tabular}

Table 2: Difference between parameters in subgroup A, B and C ( represented as p-value ).

\begin{tabular}{|c|c|c|c|}
\hline Parameter & Subgroup A and B & Subgroup B and C & Subgroup A and C \\
\hline $\begin{array}{c}\text { Age } \\
\text { (years) }\end{array}$ & $p>0.05$ & $p>0.05$ & $p>0.05$ \\
\hline $\begin{array}{c}\text { Serum Mg } \\
\text { (mmol/L) }\end{array}$ & $P<0.001$ & $p<0.001$ & $p<0.001$ \\
\hline $\begin{array}{c}\text { Serum Cu } \\
\text { ( } \mathbf{m m o l} / \mathbf{L} \text { ) }\end{array}$ & $p<0.001$ & $p<0.001$ & $p<0.001$ \\
\hline Parity number & $p>0.05$ & $p>0.05$ & $p>0.05$ \\
\hline
\end{tabular}


Serum Magnesium and Copper Levels.........

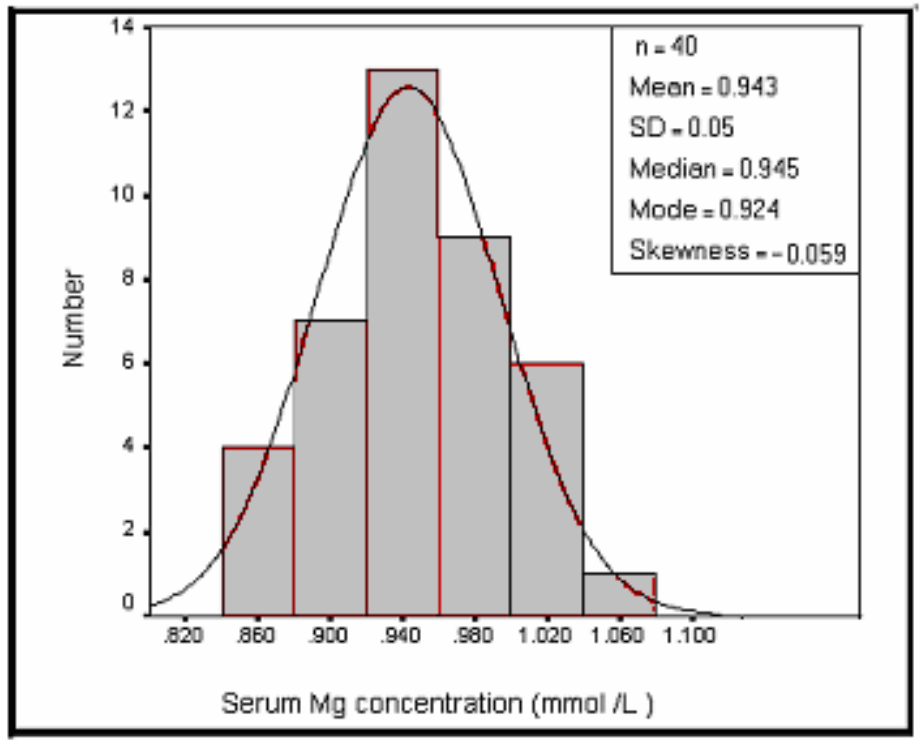

Fig. 1: Distribution of serum Mg cocentration in group I.

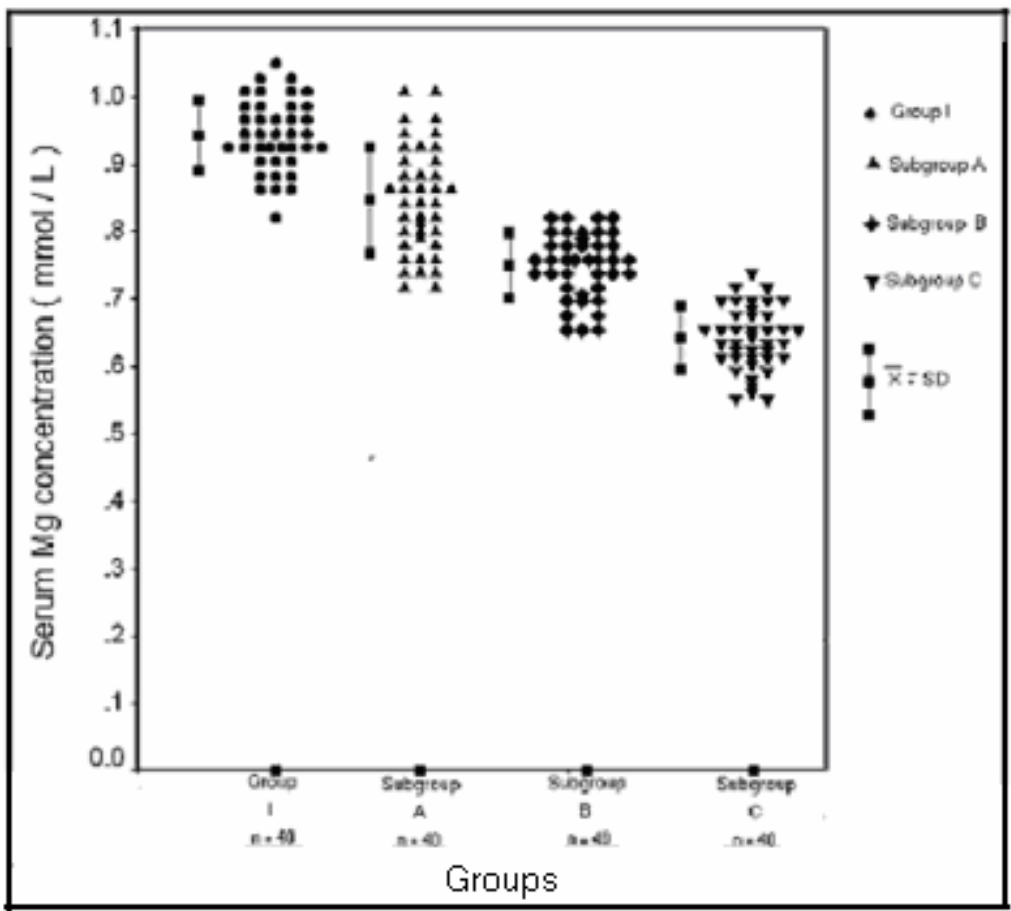

Fig. 2: Comparison of serum Mg concentration in group I, subgroup A, B, and C. 


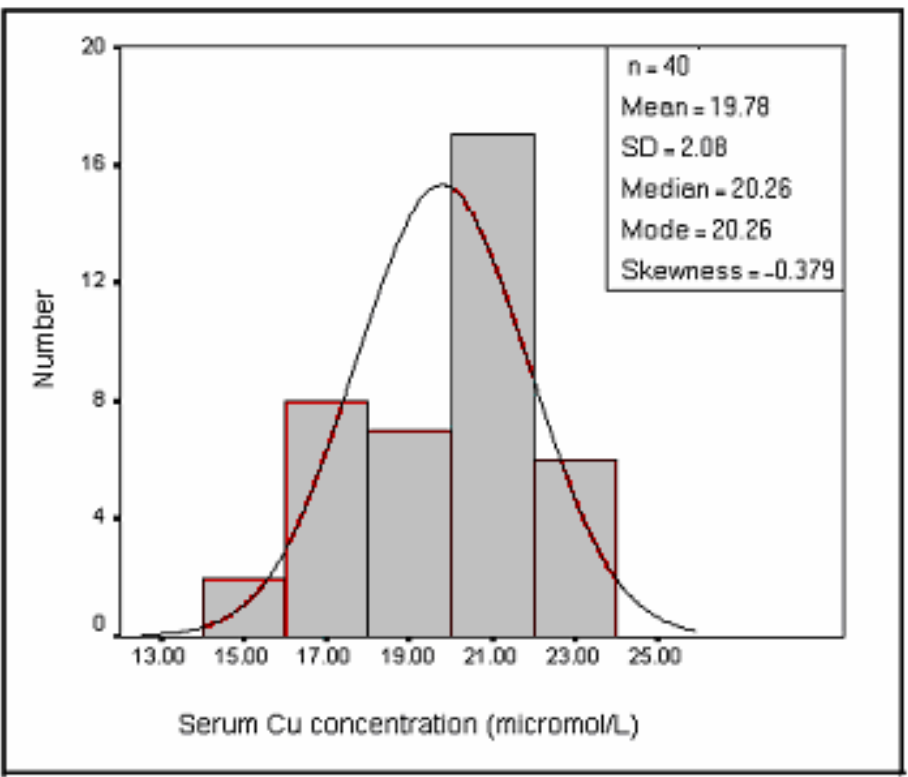

Fig. 3: Distribution of serum Cu cocentration in group I.

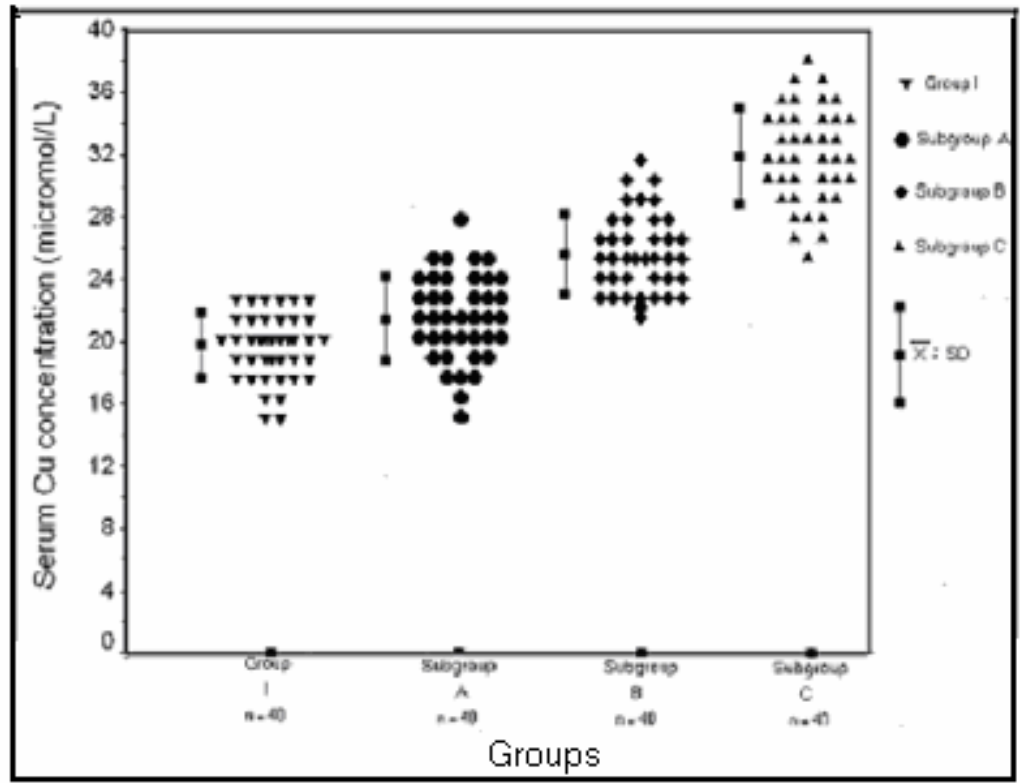

Fig. 4: Comparison of serum Cu concentration in group I, subgroup A, B, and C. 


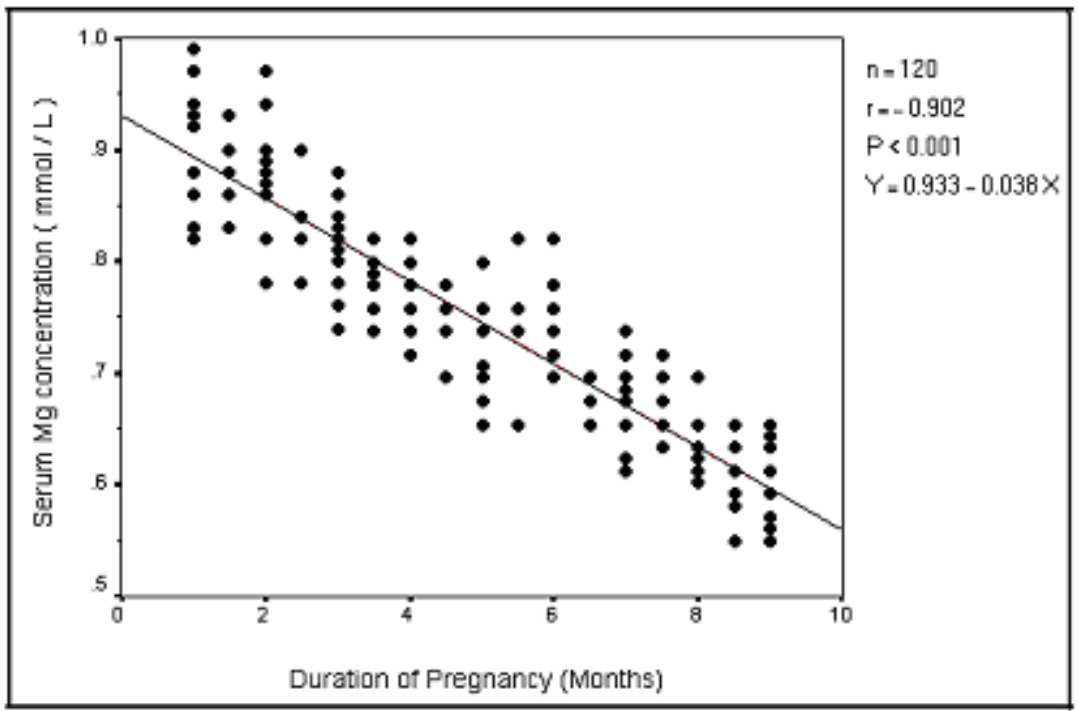

Fig. 5: Correlation between serum Mg and duration of pregnancy in group II.

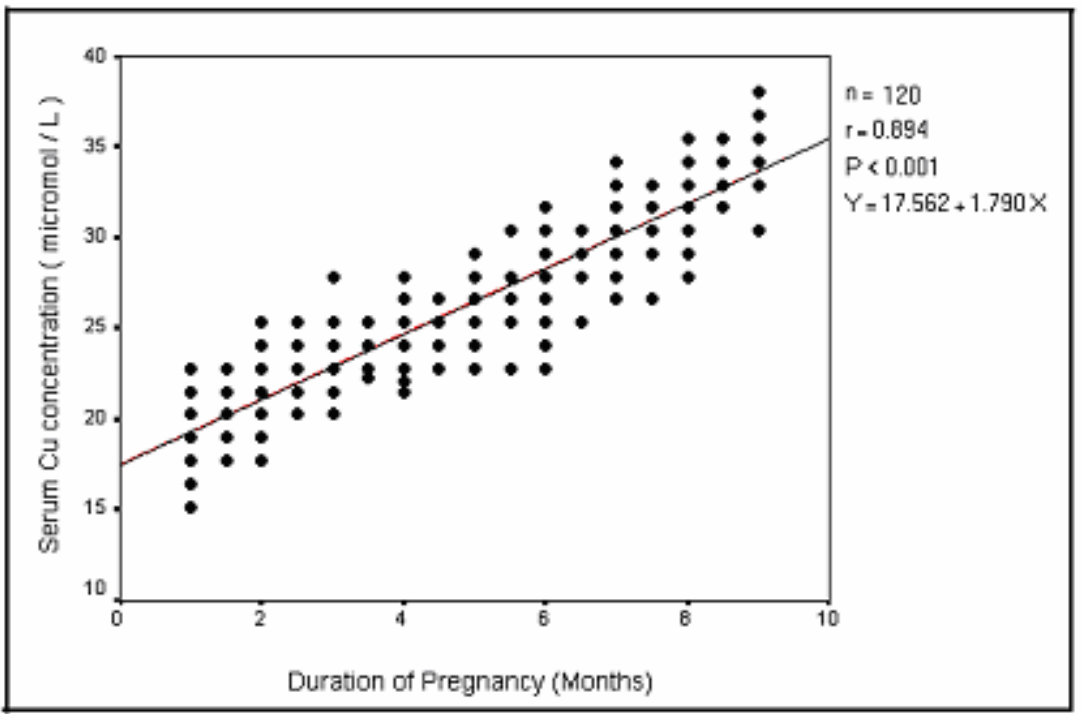

Fig. 6: Correlation between serum $\mathrm{Cu}$ and duration of pregnancy in group II.

\section{RESULTS AND DISCUSSION}

Serum Mg concentration in group I showed a normal distribution pattern with the reference range of $0.540-0.960 \mathrm{mmol} / \mathrm{L}$ (Fig. 1) that little differ from the international reference range $(0.617-0.946 \mathrm{mmol} / \mathrm{L})$ (Abbassi-Ghanavati et al., 2009), the difference is probably due to the difference in study location and to nutritional status.

The $\overline{\mathrm{x}} \pm \mathrm{SD}$ of serum Mg concentration in group I and II were $0.94 \pm 0.052$ and 0.75 $\pm 0.105 \mathrm{mmol} / \mathrm{L}$ respectively with significant lower value in group II compared with group I $(p<0.001$, Table 1, Fig 2). 
The $\overline{\mathrm{X}} \pm$ SD of serum Mg concentration in subgroup A, B and C were $0.846 \pm 0.079$, $0.750 \pm 0.048$ and $0.641 \pm 0.047 \mathrm{mmol} / \mathrm{L}$ respectively with significant lower value in subgroup B and C compared with subgroup A ( $p<0.001$, Table 2, Fig. 2$)$ and in subgroup C compared with subgroup B $(p<0.001$, Table 2, Fig. 2). In comparison with group I; all subgroup A, B and C have significant lower value ( $p<0.001$, Table 1, Fig. 2).

In group II a significant negative correlation $(p<0.001)$ was exist between duration of pregnancy and serum $\mathrm{Mg}$ concentration (Fig. 5) with r-value $=-0.902$, no such correlation was exist in group I.

In comparison with non-pregnant women serum $\mathrm{Mg}$ concentration during pregnancy was significantly lowered to a value considered to be Mg deficiency (Table 1; Fig. 2), starting appears at first trimester and continues to decline during the rest of pregnancy (Table 1, 2; Fig. 2) having a significant negative correlation with pregnancy duration (Fig. 5). These findings are in agreement with other studies showed high prevalence of $\mathrm{Mg}$ deficiency among pregnant women in the developing world (De flamingh and Van der merwe, 1984; Wilson et al., 1985).

The reduction in this study was correlated with the time of gestation this agree with other study of Abbassi-Ghanavati et al., 2009. Many explanations behind this reduction, it is most likely due to the fetus and placenta absorb huge amounts of nutrients particularly magnesium from the mother. This depletion of magnesium with not enough intake of magnesium by the mother is hypothesized to be the cause of postpartum depression (Eby and Eby, 2006).

Hypomagnesemia during pregnancy has been attributed to hemodilution and to estrogen domination to which these women are exposed (Dale and Sinpson, 1992). Mg levels significantly decreased during $9^{\text {th }}$ month of geslevels were reported to be higher in Pakistani women compared to levels elsewhere in the world (Husain and Sibby, 1993). Another explanation for this reduction is nutritional status during pregnancy (De flamingh and Van der merwe, 1984). We note most dietary habit for pregnant women participate in this study is not good and they suffering from inadequate dietary intake of magnesium.

It is suggested that inadequate dietary intake of magnesium contributes greatly to the negative magnesium balance associated with pregnancy (Seelig, 1980).

Mg absorption and elimination depend on a very large number of variables (Johnson, 2001). Even though $\mathrm{Mg}$ is readily available in food, the large number of favorable conditions required for its absorption and retention often result in a deficiency. $\mathrm{Mg}$ absorption requires plenty of $\mathrm{Mg}$ in the diet, Selenium (Se), vitamins B6 and D (Johnson, 2001).

This reduction of $\mathrm{Mg}$ level during pregnancy may be due to insufficient water intake, a very common phenomenon, has the same effect as high sodium intake, causing increased elimination of Mg, in order to increase the salinity of the urine (Johnson, 2001).

Therefore, in this study after exclusion of other factors affecting serum $\mathrm{Mg}$ level in both group I and II including age, past-medical, past-surgical and drug history, the reduction of serum $\mathrm{Mg}$ level during pregnancy is mainly attributed to fetal growth demand or because of nutritional status during pregnancy.

Serum $\mathrm{Cu}$ concentration in group I showed a normal distribution pattern with the reference range of $15.62-23.95 \mu \mathrm{mol} / \mathrm{L}$ (Fig. 4) that little differ from the international 
reference range (10.99 - $21.98 \mu \mathrm{mol} / \mathrm{L})$ (Abbassi-Ghanavati et al., 2009) the difference is probably due to the difference in study location and to nutritional status.

On the other side of this study, the $\overline{\mathrm{x}} \pm \mathrm{SD}$ of serum Cu concentration in group I and II were $19.78 \pm 2.081$ and $25.34 \pm 5.063 \mu \mathrm{mol} / \mathrm{L}$ respectively with significant higher value in group II compared with group I ( $p<0.001$, Table 1, Fig. 3).

The $\overline{\mathrm{X}} \pm \mathrm{SD}$ of serum Cu concentration in subgroup A, B and C were $21.45 \pm 2.64$, $25.58 \pm 2.56$ and $31.84 \pm 3.06 \mu \mathrm{mol} / \mathrm{L}$ respectively with significant higher value in subgroup B and C compared with subgroup A ( $p<0.001$, Table 2, Fig. 4) and in subgroup C compared with subgroup B ( $p<0.001$, Table 2, Fig 4). In comparison with group I; subgroup A have significant higher value $(p<0.002)$, also subgroup $\mathrm{B}$ and $\mathrm{C}$ have significant higher value $(p<0.001)$, Table 1, Fig. 4.

In group II a significant positive correlation $(p<0.001)$ was exist between duration of pregnancy and serum $\mathrm{Cu}$ concentration (Fig. 6) with r-value $=0.894$, no such correlation was exist in group I.

In comparison with non-pregnant women serum $\mathrm{Cu}$ concentration during pregnancy was significantly increased (Table 1; Fig. 4), starting appear at first trimester and continue to increase during the rest of pregnancy (Table 1, 2) having a significant positive correlation with pregnancy duration (Fig. 6). These findings are in agreement with other studies showed $\mathrm{Cu}$ increased among pregnant women in the developing world (Das, 2009; Etebary et al., 2010; Upadhyaya et al., 2004). The increase in our study was correlated with the duration of pregnancy and this agrees with other studies of (Abbassi-Ghanavati et al., 2009; Baig et al., 2003).

Many explanations behind this increase, that caused by a parallel increase in ceruloplasmin, a $\mathrm{Cu}$ - binding protein as a result of elevated level of maternal estrogen during pregnancy (Farzin et al., 2009; Henkin et al., 1971).

Estrogen is not considered the only factor for increasing ceruloplasmin level, adrenal hornones, which increase in pregnancy, is also known to increase ceruloplasmin synthesis (Evans, 1973; Fuchs and Klopper, 1977).

The level of ceruloplasmin might be increased due to an acute-phase response, estrogens or pregnancy (Crook, 2006).

Das, 2009 study showed a significant increase in serum copper was observed with onset of pregnancy, and it continued to rise and doubled by the end of pregnancy. Furthermore (Bro et al., 1988) noted that copper concentration increase during pregnancy and decrease after delivery.

The $\overline{\mathrm{X}} \pm \mathrm{SD}$ of the parity number in group II and in subgroup A, B and C were $2.15 \pm$ $1.71,2.31 \pm 1.70,2.18 \pm 1.54$ and $2.13 \pm 2.17$ respectively (Table 1 ) with non significant differences between subgroups ( $p>0.05$, Table 2$)$, and non significant correlation existing between the parity number and serum $\mathrm{Mg}$ and $\mathrm{Cu}$ concentrations.

The results in this study showd that $\overline{\mathrm{X}} \pm$ SD of the age in group I and II were $24.8 \pm 4.6$ and $25.2 \pm 4.3$ years respectively with non significant difference between them ( $p>0.05$, Table 1). The $\bar{X} \pm$ SD of the age in subgroup A, B and C were $25.0 \pm 4.5,24.9 \pm 4.7$ and $25.0 \pm 4.1$ years respectively with non significant differences between them $(p>0.05$, Table 2 ) or in comparison with group I ( $p>0.05$, Table 1$)$.

In group I and II and in subgroup A, B and C; no significant correlation was exist between the age and serum $\mathrm{Mg}$ and $\mathrm{Cu}$ concentrations. However, the explanation of mother 
age correlation is idiopathic and the difference with this study is probably due to the difference in study location and to a relatively narrow age group selected in this study.

\section{CONCLUSSION}

In conclusion, the reduction of serum Mg level during pregnancy start to appear at first trimester, and continue to decline during the rest of pregnancy, therefore, it is recommended to introduce serum Mg measurement as a routine test during pregnancy with the use of optimal dose of Mg supplemental therapy.

But serum $\mathrm{Cu}$ level increased at first trimester, and continue to increase during the rest of pregnancy, therefore it is recommended to introduce serum $\mathrm{Cu}$ measurement as a routine test during pregnancy with avoid supplemental therapy increase copper and cerreloplasmin.

\section{REFERENCES}

Abbassi-Ghanavati, M.; Greer, L.G.; Cunningham, F.G. (2009). Pregnancy and laboratory studies. A reference table for clinicians. Obstet. Cynecol. 114(6),1326-1331.

Akinloye, O.; Oyewale, O. J.; Oguntibeju, O.O. (2010). Evaluation of trace elements in pregnant women with pre-eclampsia. Afr. J. Biotechnol., 9(32), 5196-5202.

Baig, S.; Hasnain, N.U.; Ud-din, Q. (2003). Studies on Zn, Cu, Mg, Ca and Phosphorus in maternal and cord blood. J. Pakist. Med. Associat. 53(9), 417-420.

Bro, S.; Berendtsen, H.; Norgaard, E. (1988). Serum zinc and copper concentration in maternal umbilical cord blood: relation to course and outcome of pregnancy. Scand. J. Chin. Lab. Invest. 48, 805-11.

Burits, C.A.; Ashwood, E.R.; Bruns, D.E.; Sawyer, B.G. (2008). “Tietz Fundamentals of Clinical Chemistry”. 6th edn. Saunders Elsevier, Inc., U.S.A., pp.499-722.

Chap, T.L.E. (2003). “Introductory Biostatistics”. Wiely interscience., pp. 283-292.

Crook, M.A. (2006). "Clinical Chemistry and Metabolic Medicine”. 7th ed. Edward Arnold (Publishers) Ltd., p. 230.

Dale, F.; Sinpson, G. (1992). Serum magnesium levels of women taking an oral or long term injectable progestational contraceptive. Obstet. Gynecol., 39,115-119.

Das, I. (2009). Trace Elements in Human Pregnancy. University of Saskatchewan, Saskatoon, Canada. pp. 40-55.

De flamingh, J.P.G.; Van der merwe, J.V. (1984). A serum biochemical profile of normal pregnancy. S. Afr. Med. J., 65, 552-555.

Durlach, J.; Durlach, V.; Rayssiguier, Y.; Ricquier, D.; Goubern, M.; Bertin, R.; Bara, M.; Guiet-Bara, A.; Olive, G.; Mettey, R. (1991). Magnesium and thermoregulation. I. Newborn and infant. Magnes. Res., 4(3),137-152.

Eby, G.A.; Eby, K.L. (2006). Rapid recovery from major depression using magnesium treatment. Med Hypotheses, 67,362-370.

Etebary, S.; Nikseresht, S.; Sadeghipour, H.R.; Zarrindast, M.R. (2010). Postpartum depression and role of serum trace elements. Iran J. Psychiatry, 5(2),40-46.

Evans, G. (1973). Copper haneostatsis in mammalian systems. Physiol. Rev., 53, 535-570.

Farzin, L.; Moassesi, M. E.; Sajadi, F.; Amiri, M.; Shams, H. (2009). Serum levels of antioxidants ( $\mathrm{Zn}, \mathrm{Cu}, \mathrm{Se})$ in healthy volunteers living in tehran . Biol. Trace Elem. Res., 129, 36-45. 
Fuchs, F.; Klopper, A.(1977). “Endocrinology in Pregnancy”. 2nd ed., Harper and Row Publishers, N.Y.

Henkin, R.; Marshall, J.; Meret, S. (1971). Maternal-fetal metabolism of copper and zinc at term. Am. J. Obstet. Gynecol. 110, 131-134.

Henry, J.B. (2001). “Clinical diagnosis and management by laboratory methods”. 20th ed., W.B. Saunders Company, U.S.A., pp.206-209.

Husain, S.M.; Sibby, C.P.(1993). Magnesium and pregnancy. Miner Electrolyte Metab. 19,295-307.

Johnson, S.(2001). The multifaceted and widespread pathology of magnesium deficiency. Medical Hypotheses, 56(2), 163-170.

Jones, D. (2002). "Pharmaceutical Statistics”. Pharmaceutical Press., pp. 25-46.

Khachatryan, A.; Nikos, M. (2000). "Biostatistics and Epdemiology” 2nd ed. Mc GrawHill., pp. 20-23.

Landau, S.; Everitt, B.S. (2003). “A Handbook of Statistical Analyses using SPSS”. A CRC Press Company USA.

Loyke, H.F. (2002). Effects of elements in human blood pressure control. Biol. Trace Elem. Res., 85,193-209.

Marshall, W.J.; Bangert, S.K. (2008). “Clinical Chemistry” 6th ed., Mosby Elsevier., p.250

Murray, R.K.; Bender, D.A.; Botham, K.M.; Kennelly, P.J.; Rodwell, V.W.; Weil, P.N. (2009). “Harper’s illustrated Biochemistry”. 28th edn., Lange Medical Book/ McGraw-Hill, pp.573-574.

Payne-James, J.; Grimble, G.K.; Silk, D.B.A. (2001). “Artificial Nutrition Support in Clinical Practice”. 2nd ed., Greenwich Medical Media Limited, London, p.449.

Seelig, M.S. (1980). Magnesium deficiency in rhe paehogenesis of Disease. Plenum Medical, 45.

Upadhyaya, C.; Mishra, S.; Ajmera, P.; Sharma, P. (2004). Serum iron, copper and status in maternal and cord blood. Ind. J. Clinic. Biochemist., 19(2), 48-52.

Vasudevan, D.M.; Sreekumari, S. (2005). "Textbook of biochemistry for medical students”. 4th edn., Jaypee Brothers medical publishers, 305 p.

Wardlaw, G.M.; Hampl J.S. (2007). “Perspectives in Nutrition”. 7th ed., McGraw-Hill Companies, Inc., NewYork., pp. 416-426.

Wilson, H.J; Dixon-Mclver, D.; Sargon, R.; Sizoo, M.; France, J.T. (1985). Plasma magnesium concentration in the third trimester of pregnancy and its relationship to plasma volume. J. Obstetr. Gynaecol., 5(3),146-150. 